\title{
EFFECT OF DIETARY SUPPLEMENTATION OF SOME ORGANIC ACIDS MIXTURES ON PERFORMANCE OF BROILER CHICKS
}

\author{
A.A. Ghazalah ${ }^{1}$; Kout El-kloub M.El. Moustafa ${ }^{2}$, A.M. Atta ${ }^{1}$ and Riry, F.H. Shata ${ }^{2}$ \\ ${ }^{1}$ Dept. of Anim. Production, Fac. of Agric., Cairo Univ., Giza, Egypt. \\ ${ }^{2}$ Anim. Prod. Res. Institute, Agric. Res. Center., Ministry of Agric., Dokki, Giza, Egypt.
}

SUMMARY

$\mathrm{T}$ This study was carried out to investigate the effects of feeding some organic acids mixtures on broilers. Four organic acids (OAs): formic (FA) at $0.50 \%$, acetic (AC) at $0.25 \%$, citric (CA) at $2 \%$ and butyric (BA) at $0.2 \%$ were used as mixtures. A total number of 210 one day old male Arbor Acres broiler chicks were randomly divided into 7 treatment groups, each in three replicates of 10 chicks per replicate. The first group fed the basal diet without supplementation and served as control (T1). While, the other groups received the basal diet supplemented with the tested organic acids mixtures as follow: $\mathrm{T} 2(0.5 \% \mathrm{FA}+0.25 \% \mathrm{AC}), \mathrm{T} 3(0.5 \% \mathrm{FA}+2 \% \mathrm{CA}), \mathrm{T} 4$ $(0.5 \% \mathrm{FA}+0.2 \% \mathrm{BA}), \mathrm{T} 5(0.25 \% \mathrm{AC}+2 \% \mathrm{CA}), \mathrm{T} 6(0.25 \% \mathrm{AC}+0.2 \% \mathrm{BA})$ and $\mathrm{T} 7(2 \% \mathrm{CA}+0.2 \% \mathrm{BA})$. The experiment lasted up to 42 day of age. Performance, $\mathrm{pH}$ of feed and some GI-tract segents, cecal bacteria count, blood metabolites, acceptability and nutrients digestibility were measured. Results indicated that:

1) Most of OAs mixtures improved performance of broiler chicks measured as feed conversion ratio, protein utilization efficiency and European Production Efficiency Index (EPEI) compared with the control group.

2) Dietary OAs mixtures improved some nutrients digestibility of the experimental diets compared with the control group.

3) Blood plasma content of calcium, phosphorus, total protein and globulin were significantly increased by feeding OAs mixtures compared with the control group.

4) Relative weights of lymphoid organs (spleen and bursa of fabrics) of chicks fed OAs mixtures were mostly higher than the control.

5) The $\mathrm{pH}$ values were significantly reduced in crop and gizzard of the chicks fed OAs mixtures compared to chicks fed the control.

6) Most of OAs mixtures significantly increased lactobacillus count and significantly lowered the population of the anaerobic and $E$. coli count of ceca.

In conclusion, $0.5 \% \mathrm{FA}, 0.25 \% \mathrm{AC}, 0.2 \% \mathrm{BA}$ and $2 \% \mathrm{CA}$ as mixtures may improve performance and health of broiler chickens.

Keywords: Organic acids, broiler, performance, digestibility, serum, $\mathrm{pH}$ and bacteria.

\section{INTRODUCTION}

It is interested to investigate potential alternatives of antibiotic growth promoters in poultry diets to maintain good growth performance and intestinal microbial populations, particularly to control the growth of harmful bacteria. Several organic acids have been reported to improve growth performance, feed efficiency, and mineral absorption (Denil et al ., 2003 and Kout Elkloub et al., 2014).

Some researchers have suggested that organic acids can be used to control intestinal microbial growth (Ecklund, 1983). Also the addition of organic acids had statically effects regarding the decrease in the counts of mould, yeast in feed and pathogenic intestinal bacteria (i.e., total aerobic bacteria, E. coli, salmonella and staphylococci) as reported by Panda et al. (2009); Akyrek et al.(2011) and Kout Elkloub et al.,(2014). Their principle is to lower and supplies the $\mathrm{pH}$ in the stomach and intestines so that the gut environments become too acidic for normal bacterial growth. Additionally, they improve protein digestion in young animal by stimulating pancreatic enzyme secretion (Mellor, 2000). Thus, dietary OAs can suppress the growth of pathogenic bacteria, encourage the growth of beneficial microflora and ensure that the enzymes function is at maximal capacity (Ricke, 
2003 and Dibner, 2004). Practically, organic acids work in poultry not only as a growth promoter but also as a meaningful tool of controlling all enteritis bacteria, both pathogenic and non-pathogenic (Naidu, 2000 and Wolfenden et al., 2007). Moreover, feeding OAs are believed to have several beneficial effects such as improving feed conversion ratio, growth performance, enhancing minerals absorption and accelerating recovery from fatigue (Denli et al., 2003; Abdel-Fattah et al., 2008 and Banday et al., 2010) and also providing people with healthy and nutritious poultry products (Patten and Waldroup,1988). Dietary acidification increases gastric proteolysis and protein and amino acid digestibility. The acid anion of such OAs has been shown to complex with $\mathrm{Ca}, \mathrm{P}, \mathrm{Mg}$ and $\mathrm{Zn}$, resulting in absorbability improvement of these minerals. Furthermore, OAs serves as substrates in the intermediary metabolism (Kirchgessner and Roth, 1988). Organic acids have beneficial effects in poultry production by reducing the gut $\mathrm{pH}$ and bacterial growth intolerant to $\mathrm{pH}$ variations (Ao et al., 2009), thus providing better intestinal health for the bird to obtain maximum nutrient absorption. Moreover, organic acids have been used to improve poultry performance, perhaps, by inhibiting the intestinal bacteria competing with the host animals for available nutrients (Attia et al., 2012). The main action of dietary acidification is a fortification of the intestinal mucosal barrier function against adverse agents such as toxic bacterial metabolites (Smulikowska $e t$ al., 2010).

The objectives of this study aimed to investigate the optimal supplementation of organic acids being formic (FA), acetic (AC), citric (CA) and butyric acids (BA) as mixtures on performance, nutrients digestibility, blood metabolites, health (small intestinal microbial flora, $\mathrm{pH}$ ) and meat quality of broiler chickens.

\section{MATERIALS AND METHODS}

The experimental work of this study was carried out at Gezerit Elshier Poultry Research Station, AL- Kanater AL-Khairia, Egypt. A total number of 210 one-day old male Arbor Acres broiler chicks were randomly taken and divided into 7 treatment groups, each in three replicates (10 birds / replicate) as shown in Table (1). Feed and water were available all time. The study aimed to study the effective use of mixing four organic acids (OAs) FA at $0.5 \%, \mathrm{AC}$ at $0.25 \%, \mathrm{BA}$ at $0.2 \%$ and $\mathrm{CA}$ at $2.0 \%$. These organic acids at such levels were evaluated in broiler diets through their effects on broiler performance, nutrients digestibility, some blood metabolites, $\mathrm{pH}$ level of some gastrointestinal tract segments, microbiological content of ceca, mortality, European Production Efficiency Index (EPEI) and overall acceptability of chicken meat.

The experimental treatments included different mixtures of four FA, AC, CA and BA which were used in different combinations in addition to the control group without OAs supplementation (Table 1). Basal diets were formulated (Table 2) to meet the nutrients requirements of Arbor Acres broiler at starter (1-14d), grower (15-28d) and finisher (29-42d) periods.

Body weights (BW), feed consumption (FC) and mortality rate were recorded biweekly and average body weight gains (BWG), feed conversion ratio (FCR) and European Production Efficiency Index (EPEI) were calculated.

At 6 weeks of age, three birds from each treatment were randomly taken and housed in individual cages to determine the digestibility coefficients of nutrients for only the experimental finisher diets. The analyses of feed and dried excreta were done according to A.O.A.C. (1990). Fecal nitrogen was determined according to Jakobsen et al. (1960).

At the end of the experiment (42 day), three birds / treatment were randomly taken and slaughtered to obtain the acceptability of chicken meat and lymphoid organs. Blood samples were taken to determine plasma content of total protein, albumin, globulin, cholesterol, calcium and phosphor, using commercial kits. The $\mathrm{pH}$ in feed and different parts of the gastrointestinal tract was determined according to Al-Natour and Alshawabkeh (2005), as well as the definition and count of the gastrointestinal tract microbial content (Quinn et al., 1992).

The obtained data were statistically analyzed using linear models procedure described in SAS users guide (SAS, 1990). Differences between means were tested using Duncan's Multiple Range Test (Duncane's, 1955). One -way analysis model was applied:

$\mathrm{Y}_{\mathrm{ij}}=\mu+\mathrm{T}_{\mathrm{i}}+\mathrm{E}_{\mathrm{ij}}$

Where: $\mathrm{Y}_{\mathrm{ij}}=$ Observations

$\mu=$ the overall mean

Ti $=$ Effect of $\mathrm{i}^{\text {th treatments }}$

$\mathrm{E}_{\mathrm{ij}}=$ Experimental error 
Egyptian J. Nutrition and Feeds (2015)

\section{RESULTS AND DISCUSSION}

\section{Productive performance:}

The effect of used organic acids mixtures on growth performance are summarized in Table 3. The results indicated that at 42 days of age, the chicks fed $\mathrm{T}_{2}(0.5 \% \mathrm{FA}+0.25 \% \mathrm{AC})$ recorded the heaviest LBW (2089g) and the best BWG (1973g) compared with all treatments and control group. While those fed $\mathrm{T}_{5}(0.25 \% \mathrm{AC}+2 \% \mathrm{CA})$ had significantly lower value of LBW (2002 g) and BWG (1885g) compared to T2. However, no significant differences were observed among the other mixtures of OAs. These results are in harmony with the results of Vale et al. (2004) who reported that giving broiler OAs (70\% FA and 30\% PA) at levels of $0.25,0.50,1.0$ or $2.0 \%$ increased BW and BWG at 0.25 and $0.5 \%$ levels and decreased at $2 \%$ level compared to the control. Also, Senkoylu et al. (2005 and 2007) indicated that weight gain of broilers at 21 and $35 \mathrm{~d}$ were significantly $(\mathrm{p}<0.001)$ increased by supplementing $3 \mathrm{~g}$ OAs$/ \mathrm{kg}$ feed compared to the control. Also, Viola et al. (2008) found that adding mixtures of OAs increased BWG of birds at 35 days of age. In addition, Vieira et al. (2008) mentioned that a blend of OAs (40\% LA, 7\% AC, 5\% phosphoric acid and 1\% BA) improved BW, but did not affect BWG ( $\mathrm{p} \leq$ 0.05). Samanta et al. (2010) found that supplementation of OAs blend $(10 \mathrm{~g}$ and $20 \mathrm{~g} / \mathrm{kg})$ to the diets increased LBW linearly compared to the control. Also, Asma and Nagra (2010) reported that chicks receiving $0.6 \%$ blend of OAs as 7:3 ratio of FA and PA had better BWG than the control. On the other hand, Isabel and Santos (2009) noticed that birds fed organic acid salts $(5,120 \mathrm{ppm}$ of FA and 2,080 ppm of PA) had no influence on BW or BWG. Also, Smulikowska et al. (2010) found no significant effect on BWG in birds fed organic acid blend (6 $\mathrm{g} / \mathrm{kg}$ ).

The lowest values $(\mathrm{P}<0.01)$ of cumulative feed consumption $(\mathrm{FC})$ recorded by the chicks fed $\mathrm{T}_{6}(0.25 \%$ $\mathrm{AC}+0.2 \% \mathrm{BA})(3436 \mathrm{~g})$ at $7-42 \mathrm{~d}$ compared to the other treatments and control group, accordingly, recorded significantly the best FCR values compared to $\mathrm{T}_{3}(0.5 \% \mathrm{FA}+2 \% \mathrm{CA}), \mathrm{T}_{7}(2 \% \mathrm{CA}+0.2 \% \mathrm{BA})$ and control group $\left(\mathrm{T}_{1}\right)$. The best FCR occurred by $\mathrm{T}_{6}(0.25 \% \mathrm{AC}+0.2 \% \mathrm{BA})$ followed by $\mathrm{T}_{2}(0.5 \% \mathrm{FA}+0.25 \% \mathrm{AC})$ compared to the other treatments. These findings agree with those obtained by Senkoylu et al. (2005) who found that the addition of $3 \mathrm{~g}$ OAs / kg to broiler diet significantly ( $<<0.001)$ improved FC and FCR at 21 and 35 days. Also, Senkoylu et al. (2007) noted significantly (P < 0.001) improved FCR by using combination of FA and PA at 21 days of age. Samanta et al. (2010) found that FCR was better in broilers fed OAs blend (10g and 20g/kg) for 35 days. Asma and Nagra (2010) found that adding $0.6 \%$ blend of OAs as 7:3 ratio of FA and PA performed better FC than the control, however no significant difference was observed in FCR. On the other hand, Alp et al. (1999) found that no effect was obtained on FCR when used OAs combination (LA, FUA, PA, CA and FA). Mikulski et al. (2008) found an inferior FCR when used blend of FA and PA $(5.0 \mathrm{~g} / \mathrm{kg})$ and blend of citric, fumaric, orthophosphoric and malic acids, compared to the control. Also, Smulikowska et al. (2010) found that organic acid blend (6 g/kg) did not significantly affect FC compared to the control.

The addition of OAs mixtures recorded higher protein utilization efficiency and EPEI compared to the control group without significant differences between them (Table 3). Numerically, $\mathrm{T}_{2}(0.5 \% \mathrm{FA}+0.25 \% \mathrm{AC})$ gave higher EPEI compared to other treatments and the control.

The high viability of all birds during the experimental periods occurred. The mortality could have accounted to natural cases (Table 3).These results were in harmony with the result of Isabel and Santos (2009) and Samanta et al. (2010) who reported that adding mixtures of organic acids to broiler diet had no influence on mortality. This could be attributed to the effect of such OAs against different pathogenic microorganisms, particularly at younger age or to the protective action against diseases and reduction of mold growth which inhibits the formation of aflatoxins.

\section{Nutrients digestibility:}

Analysis of variance showed significant differences for the digestion coefficients of OM, CP, EE and NFE at 42 days of age (Table 4$)$. The best significant digestibility of OM and NFE recorded by $\mathrm{T}_{6}(0.25 \% \mathrm{AC}+0.2 \% \mathrm{BA})$. Chicks fed OAs specially $\mathrm{T}_{2}(0.5 \% \mathrm{FA}+0.25 \% \mathrm{AC})$ and $\mathrm{T}_{3}(0.5 \% \mathrm{FA}+2 \% \mathrm{CA})$ recorded the highest values of $\mathrm{CP}$ digestibility. While, the lower values recorded by chicks fed $\mathrm{T}_{5}(0.25 \% \mathrm{AC}+2 \% \mathrm{CA})$. All treatments had significantly higher values of EE digestibility compared to the control except $\mathrm{T}_{4}$. No significant differences for the digestion coefficients of CF when used OAs. Similarly, NR values were higher on all treatments but not significantly compared to the control group. These results did not agree with those obtained by Gheisari et al. (2007) who found that protected OAs had no significant $(\mathrm{p}<0.05)$ effect on ileal protein digestibility. Also, 
Mikulski et al. (2008) showed that dry matter concentration in the ileal digesta were unaffected by using a blend of (FA and PA) or blend of (citric, fumaric, orthophosphoric and malic acid).

\section{Overall Acceptability:}

No significant differences between chicks fed diets supplemented with OAs mixture and the control group for dressing, thigh, gizzard, abdominal fat, liver, heart and total edible parts percentages (Table 5). Breast percentages was significantly increased $(\mathrm{p}<0.01)$ by $_{7}(2 \% \mathrm{CA}+0.2 \% \mathrm{BA})$ compared to those of to $\mathrm{T}_{3}(0.5 \% \mathrm{FA}+2 \% \mathrm{CA})$, while, no significant differences were observed between the other treatments. These results are in agreement with those obtained by Alp et al. (1999) who found that carcass weight and dressing percentage were not affected by OAs combination (LA, FuA, PA, CA and FA) added to the broiler feed. Vieira et al. (2008) found that the yield of carcass and commercial cuts were not improved by OAs (40\% LA, 7\% AC, 5\% phosphoric and 1\% BA) supplemented to the broiler feed. Also, Isabel and Santos (2009) noticed that carcass weight was not influenced by supplementation of OAs mixture. Samanta et al. (2010) declared that no effect was observed on the dressing percentage, but breast and thigh weights increased linearly with adding OAs blend (1or $2 \mathrm{~g} / \mathrm{kg} \mathrm{OAB}$ ). Asma and Nagra (2010) noted that receiving $0.6 \%$ blend of OAs as 7:3 ratio of FA and PA had no adverse effect on dressing percentage, however abdominal fat was decreased with OAs blend compared to the control group.

\section{Blood constituents:}

The results of the estimated blood plasma parameters and lymphoid organs of broiler at 42 days old as affected by dietary mixture of OAs are presented in Table 6. Generally, dietary mixture of OAs had significant effects on all blood plasma parameters. All treatments had significantly high levels of plasma calcium and phosphorus compared to control group. The highest concentration of plasma calcium and phosphorus occurred by $\mathrm{T}_{2}(0.5 \% \mathrm{FA}+0.25 \% \mathrm{AC})$ compared with other treatments and control group. Chicks of $\mathrm{T} 2$ recorded significantly lower ALT values compared to control group. While, no significant differences were observed among the other treatments. The current results demonstrated that dietary OAs significantly affected AST. Chicks fed the control diet recorded significantly the lowest value (36.67), however $\mathrm{T}_{6}(0.25 \% \mathrm{AC}+0.2 \% \mathrm{BA})$ recorded highest value (60) of AST.

The results also showed that chicks of $\mathrm{T}_{7}(2 \% \mathrm{CA}+0.2 \% \mathrm{BA})$ recorded significantly the lowest value of cholesterol than the other treatments and control group. In this connection, Asma and Nagra (2010) reported that by supplementing OAs into diet at the level of $0.8 \%$ FA, $0.4 \%$ PA, or $0.6 \%$ blend of FA and PA as 7:3 ratio, plasma alkaline phosphatase, AST and ALT levels were within the normal range.

Supplementation of OAs mixtures to all treatments significantly increased plasma total protein and globulin compared to control group. Broiler chicks supplemented with organic acid mixtures recorded lower values of $\mathrm{A} / \mathrm{G}$ ratio compared to control group, except $\mathrm{T}_{3}(0.5 \% \mathrm{FA}+2 \% \mathrm{CA})$ which recorded significantly higher value.

These results indicated that mixture of OAs may improve the immune response. Globulin level has been used as an indicator of immune responses and source of antibody production. Griminger (1986) stated that high globulin level and low A/G ratio signified better disease resistance and immune response. This result is in harmony with those of Asma and Nagra (2010) who reported that formic acid supplementation into diet at blend of formic and propionic acids as 7:3 ratio, tended to increase significantly antibody titer against NDV and IBD compared to the control.

It is well known that spleen, bursa and thymus are involved in the immune system (Sturkie, 1986) and this system is responsible for producing cells and chemicals that protect the birds from the invaded microorganisms. It was clearly observed that $\mathrm{T}_{2}(0.5 \% \mathrm{FA}+0.25 \% \mathrm{AC})$ and $\mathrm{T}_{5}(0.25 \% \mathrm{AC}+2 \% \mathrm{CA})$ had significantly higher relative weights of spleen (Table 6). The results explained that chicks fed all OAs mixture had significantly higher relative weights of bursa than the control group which recorded the lowest weight. The broilers of $\mathrm{T}_{2}(0.5 \% \mathrm{FA}+0.25 \%$ $\mathrm{AC}$ ) had significantly higher relative thymus weights compared to other treatments except $\mathrm{T}_{3}(0.5 \% \mathrm{FA}+2 \% \mathrm{CA})$. These results indicate that broiler chicks fed on acidifiers had better immune organs and disease resistance. In this respect, Katanbaf et al. (1989) reported that the increase in the relative organ weight is considered as an indication of the immunological advances.

\section{Effect of organic acids mixture on $\mathrm{pH}$ in feed and different parts of the gastrointestinal Tract:}

\section{Feed pH:}

The $\mathrm{pH}$ values of starter, grower and finisher diets declined as dietary mixture of organic acids was mixed. The present results showed significant $(\mathrm{p}<0.01)$ reduction in the $\mathrm{pH}$ values of different treatments compared to the control (Table 7). 


\section{pH values of gastrointestinal Tract:}

The results indicated that OAs mixture supplementation in all treatments significantly reduced crop and gizzard $\mathrm{pH}$ values compared to the control. While, the broiler fed the control showed significantly lower duodenum $\mathrm{pH}$ compared with $\mathrm{T}_{5}(0.25 \% \mathrm{AC}+2 \% \mathrm{CA}), \mathrm{T}_{6}(0.25 \% \mathrm{AC}+0.2 \% \mathrm{BA})$ and $\mathrm{T}_{7}(2 \% \mathrm{CA}+0.2 \% \mathrm{BA})$. However, no differences were observed among other dietary treatments. The results showed that jejunum $\mathrm{pH}$ was significantly lower in chicks of $\mathrm{T}_{1}$ compared to $\mathrm{T}_{5}(0.25 \% \mathrm{AC}+2 \% \mathrm{CA})$ and $\mathrm{T}_{6}(0.25 \% \mathrm{AC}+0.2 \% \mathrm{BA})$. The lower $\mathrm{pH}$ in the ileum was recorded by $\mathrm{T}_{4}(0.5 \% \mathrm{FA}+0.2 \% \mathrm{BA})$, compared to $\mathrm{T}_{2}(0.5 \% \mathrm{FA}+0.25 \% \mathrm{AC}), \mathrm{T} 3(0.5 \% \mathrm{FA}+$ $2 \% \mathrm{CA}), \mathrm{T}_{6}(0.25 \% \mathrm{AC}+0.2 \% \mathrm{BA})$ and $\mathrm{T}_{7}(2 \% \mathrm{CA}+0.2 \% \mathrm{BA})$. On the other hand, ceca was significantly lower in chicks of $\mathrm{T}_{1}$ and $\mathrm{T}_{7}$ compared to $\mathrm{T}_{4}$. While, rectum $\mathrm{pH}$ was significantly higher in chicks of $\mathrm{T}_{7}$ compared to the other treatments. The present results are in agreement with those of AL-Tarazi and Alshawabkeh (2003) who reported that dietary mixture of both FA and PA at concentrations of 0.5 to $1.5 \%$, significantly $(\mathrm{P}<0.05)$ lowered the $\mathrm{pH}$ of the crop and cecal contents in all groups, except the group treated with $(0.5 \% \mathrm{FA}$ and $0.5 \% \mathrm{PA})$ compared to the control. Alp et al. (1999) found that mean ileal $\mathrm{pH}$ was significantly $(\mathrm{p}<0.05)$ lower in chickens fed OAs combination (LA, FUA, PA, CA and FA) at $3 \mathrm{~g} / \mathrm{kg}$ diet compared to the control.

Similarly, Gheisari et al. (2007) found that $\mathrm{pH}$ of digest in ileum was significantly $(\mathrm{p}<0.05)$ decreased with increasing the levels $(0.0,0.2$ and $0.4 \%)$ of protected organic acid mixtures (formic and propionic). On the other hand, Paul et al. (2007) found no significant difference in $\mathrm{pH}$ of different segments of the GIT due to OAs salts compared with the antibiotic group. However, Mikulski et al. (2008) noted that AOs blend (5.0g FA and PA/kg) significantly decreased the $\mathrm{pH}$ of the broiler crop contents, but had no effect on the $\mathrm{pH}$ of the caecal digesta compared to the control. Also, Samanta et al. (2010) found that organic acid blend (10g and $20 \mathrm{~g} / \mathrm{kg} \mathrm{OAB}) \mathrm{had}$ little effect on $\mathrm{pH}$ of the crop, proventriculus, duodenum and ileum. Also, Smulikowska et al. (2010) found that OAs blend $(6 \mathrm{~g} / \mathrm{kg})$ had no influence on the $\mathrm{pH}$ of gut digesta of birds.

\section{Effect of organic acids mixture on ceca microbial content of broiler:}

Data in Table 8 showed the effect of OAs mixture on microbial contents. The Lactobacillus bacterial counts per gram of ceca content of chicks fed dietary OAs mixture were significantly higher than the control group except $\mathrm{T}_{3}(0.5 \% \mathrm{FA}+2 \% \mathrm{CA})$ and $\mathrm{T}_{4}(0.5 \% \mathrm{FA}+0.2 \% \mathrm{BA})$. the coliform bacterial counts were significantly increased in $\mathrm{T}_{2}(0.5 \% \mathrm{FA}+0.25 \% \mathrm{AC})$ than the other treatments. On the other hand, anaerobes bacterial numbers and the population of $E$. coli were significantly ( $<0.01)$ lower in chicks fed all mixtures of OAs compared to control group. In this respect, Alp et al. (1999) used OAs mixtures (LA, FUA, PA, CA and FA) and/or zinc bacitracin in 4 treatments, T1 (control), T2 (3gm OAs mixture/ kg), T3 (0.1 gm zinc bacitracin/kg) and T4 (T2 and T3) and found that T4 had the lowest number of Enterobacteriaceae in the intestinal material compared to the other treatments. AL- Tarazi \& Alshawabkeh (2003) found that addition of OAs mixture significantly $(\mathrm{P}<0.05)$ decreased the crop and caecal S. pullorum.

Moreover, Gunal et al. (2006) found that antibiotics or OAs mixture significantly decreased total bacterial count compared to the control group. Paul et al. (2007) found that the total viable number of $E$. coli and clostridium in gut contents varied numerically among treatments, the values were statistically non-significant by feeding broilers on antibiotics or OAs. Gheisari et al. (2007) observed that supplementation of organic acid mixture (FA and PA) had significantly $(\mathrm{p}<0.05)$ increased colony count of lactobacillus and decreased coliforms in digesta at 24 and 42 days. Lactobacillus and coliforms were higher on 42 days compared to that at 24 days. Samanta et al. (2010) found that OAs (10 or $20 \mathrm{~g} / \mathrm{kg})$ did not affect E. coli and other coliform in the small intestine. Lactobacillus was quadratically higher in the OAs (10g) group than in the control. However, Hassan et al. (2010) found that the organic acid mixture (FA, calcium formate, calcium propionate and potassium sorbate or $\mathrm{CA}$, calcium formate, calcium butyrate and calcium lactate) supplemented to the broiler diets significantly decreased E. coli and salmonella bacteria counts compared to the basal diet.

It could be concluded that $0.5 \% \mathrm{FA}, 0.25 \% \mathrm{AC}, 0.2 \% \mathrm{BA}$ and $2 \% \mathrm{CA}$ as mixtures may improve performance and health of broiler chickens. 
Table (1). Design of experiment.

\begin{tabular}{ll}
\hline Treat. No & Treatment \\
\hline T1 (Control) & The basal diet \\
T2 & The basal diet $+0.5 \% \mathrm{FA}+0.25 \% \mathrm{AC}$ \\
T3 & The basal diet $+0.5 \% \mathrm{FA}+2 \% \mathrm{CA}$ \\
T4 & The basal diet $+0.5 \% \mathrm{FA}+0.2 \% \mathrm{BA}$ \\
T5 & The basal diet $+0.25 \% \mathrm{AC}+2 \% \mathrm{CA}$ \\
T6 & The basal diet $+0.25 \% \mathrm{AC}+0.2 \% \mathrm{BA}$ \\
T7 & The basal diet $+2 \% \mathrm{CA}+0.2 \% \mathrm{BA}$ \\
\hline
\end{tabular}

Table (2). Composition and calculated analysis of basal diets.

\begin{tabular}{|c|c|c|c|c|}
\hline \multicolumn{2}{|l|}{ Ingredients \% } & Starter $(1-14 d)$ & Grower(15-28d) & Finisher(29-42d) \\
\hline \multicolumn{2}{|l|}{ Yellow corn } & 59.38 & 65.15 & 71.80 \\
\hline \multicolumn{2}{|l|}{ Soybean meal $44 \%$} & 24.25 & 19.00 & 13.00 \\
\hline \multicolumn{2}{|l|}{ Corn Gluten meal $60 \%$} & 10.00 & 10.00 & 10.00 \\
\hline \multicolumn{2}{|l|}{ Corn oil } & 1.80 & 1.70 & 1.10 \\
\hline \multicolumn{2}{|l|}{ Limestone } & 1.18 & 1.09 & 1.06 \\
\hline \multicolumn{2}{|l|}{ Di-Calcium phosphate } & 1.98 & 1.75 & 1.65 \\
\hline \multicolumn{2}{|l|}{ Vit \& min. premix $*$} & 0.25 & 0.25 & 0.25 \\
\hline \multicolumn{2}{|l|}{ DL-Methionine } & 0.16 & 0.10 & 0.09 \\
\hline \multicolumn{2}{|l|}{ L-lysine HCL } & 0.50 & 0.46 & 0.55 \\
\hline \multicolumn{2}{|l|}{ Salt $(\mathrm{Na} \mathrm{Cl})$} & 0.50 & 0.50 & 0.50 \\
\hline \multirow{2}{*}{\multicolumn{5}{|c|}{$\begin{array}{l}\text { Total } \\
\text { Calculated analysis } * * \text { : }\end{array}$}} \\
\hline & & & & \\
\hline \multirow{2}{*}{\multicolumn{2}{|c|}{$\begin{array}{l}\mathrm{CP} \\
\mathrm{ME}(\mathrm{kcal} / \mathrm{kg})\end{array}$}} & 22.00 & 20.07 & 18.02 \\
\hline & & 3096 & 3159 & 3192 \\
\hline Calcium & $\%$ & 1.00 & 0.90 & 0.848 \\
\hline Available Phosphorus \% & $\%$ & 0.499 & 0.45 & 0.42 \\
\hline Lysine $\quad q$ & $\%$ & 1.349 & 1.176 & 1.086 \\
\hline Methionine & $\%$ & 0.60 & 0.52 & 0.485 \\
\hline Methionine \& cystine $?$ & $\%$ & 0.967 & 0.86 & 0.79 \\
\hline Sodium & $\%$ & 0.21 & 0.21 & 0.21 \\
\hline
\end{tabular}

Table (3). Effect of organic acid mixtures on performance of broiler chicks at 42 days of age.

\begin{tabular}{|c|c|c|c|c|c|c|c|}
\hline Tr.No. & $\begin{array}{l}\text { Live body } \\
\text { weight }(\mathrm{g})\end{array}$ & $\begin{array}{l}\text { Body weight } \\
\text { gain }(\mathrm{g})\end{array}$ & $\begin{array}{c}\text { Feed } \\
\text { consumption }(\mathrm{g})\end{array}$ & $\begin{array}{l}\text { Feed conversion } \\
\text { ratio(gfeed/g } \\
\text { gain) }\end{array}$ & $\begin{array}{c}\text { Protein } \\
\text { utilization } \\
\text { efficiency\% }\end{array}$ & EPEI & $\begin{array}{l}\text { No.of } \\
\text { dead } \\
\text { birds }\end{array}$ \\
\hline T1 & $2053^{\mathrm{ab}}$ & $1937^{\mathrm{ab}}$ & $3827^{\mathrm{a}}$ & $2.00^{\mathrm{a}}$ & 2.51 & 220.61 & 0 \\
\hline $\mathrm{T} 2$ & $2089^{\mathrm{a}}$ & $1973^{\mathrm{a}}$ & $3706^{\mathrm{a}}$ & $1.87^{\mathrm{ab}}$ & 2.73 & 245.17 & 0 \\
\hline $\mathrm{T} 3$ & $2059^{\mathrm{ab}}$ & $1943^{\mathrm{ab}}$ & $3806^{\mathrm{a}}$ & $1.97^{\mathrm{a}}$ & 2.73 & 238.19 & 1 \\
\hline $\mathrm{T} 4$ & $2038^{a b}$ & $1922^{\mathrm{ab}}$ & $3635^{a}$ & $1.90^{\mathrm{ab}}$ & 2.76 & 241.50 & 0 \\
\hline T5 & $2002^{\mathrm{b}}$ & $1885^{\mathrm{b}}$ & $3647^{\mathrm{a}}$ & $1.93^{\mathrm{ab}}$ & 2.66 & 225.60 & 1 \\
\hline T6 & $2016^{\mathrm{ab}}$ & $1900^{\mathrm{ab}}$ & $3436^{\mathrm{b}}$ & $1.80^{\mathrm{b}}$ & 2.70 & 234.19 & 0 \\
\hline $\mathrm{T} 7$ & $2022^{\mathrm{ab}}$ & $1906^{\mathrm{ab}}$ & $3816^{\mathrm{a}}$ & $2.00^{\mathrm{a}}$ & 2.53 & 219.46 & 0 \\
\hline MSE & \pm 21.78 & \pm 21.77 & \pm 57.28 & \pm 0.04 & \pm 0.09 & \pm 8.93 & \\
\hline
\end{tabular}


Table (4). Effect of dietary organic acid mixtures on nutrients digestibility and nitrogen retention of experimental finisher diets.

\begin{tabular}{lllllll}
\hline Treatments & OM & CP & EE & CF & NFE & NR \\
\hline T1 & $81.86^{\mathrm{b}}$ & $93.90^{\mathrm{ab}}$ & $76.79^{\mathrm{b}}$ & 31.17 & $82.44^{\mathrm{bc}}$ & 55.54 \\
T2 & $81.42^{\mathrm{b}}$ & $94.67^{\mathrm{a}}$ & $84.15^{\mathrm{a}}$ & 31.17 & $80.13^{\mathrm{c}}$ & 58.85 \\
T3 & $81.82^{\mathrm{b}}$ & $94.62^{\mathrm{a}}$ & $82.71^{\mathrm{a}}$ & 32.40 & $80.60^{\mathrm{bc}}$ & 56.13 \\
T4 & $82.17^{\mathrm{b}}$ & $93.94^{\mathrm{ab}}$ & $80.38^{\mathrm{ab}}$ & 29.26 & $82.16^{\mathrm{bc}}$ & 55.86 \\
T5 & $82.78^{\mathrm{ab}}$ & $93.03^{\mathrm{b}}$ & $81.60^{\mathrm{a}}$ & 29.18 & $82.92^{\mathrm{abc}}$ & 59.56 \\
T6 & $85.25^{\mathrm{a}}$ & $93.71^{\mathrm{ab}}$ & $82.40^{\mathrm{a}}$ & 30.53 & $85.90^{\mathrm{a}}$ & 61.69 \\
T7 & $83.84^{\mathrm{ab}}$ & $93.71^{\mathrm{ab}}$ & $83.27^{\mathrm{a}}$ & 29.68 & $83.82^{\mathrm{ab}}$ & 62.09 \\
MSE & \pm 0.81 & \pm 0.30 & \pm 1.39 & \pm 2.12 & \pm 0.99 & \pm 2.77 \\
\hline
\end{tabular}

${ }_{a, b, c}$ Means in the same row with different superscripts are significantly different $(P<0.01)$

Tl(control),T2(0.5\%FA+0.25\%AC),T3(0.5\%FA+2\%CA),T4(0.5\%FA+0.2\%BA, T5(0.25\%AC+2\%CA), T6 $(0.25 \%$

$A C+0.2 \% B A)$ and $77(2 \% C A+0.2 \% B A)$.

Table (5). Effect of dietary organic acid mixtures on acceptability of broiler chicks at 42 days old.

\begin{tabular}{|c|c|c|c|c|c|c|c|c|c|}
\hline Treatments & $\begin{array}{c}\text { Live } \\
\text { weight }(\mathrm{g})\end{array}$ & Dressing & Breast & Thigh & $\begin{array}{l}\text { Abdominal } \\
\text { Fat }\end{array}$ & Gizzard & Liver & Heart & $\begin{array}{c}\text { T.edible } \\
\text { parts* }\end{array}$ \\
\hline $\mathrm{T} 1$ & 2634 & 68.32 & $37.96^{\mathrm{ab}}$ & 30.36 & 1.62 & 2.50 & 2.18 & 0.48 & 73.48 \\
\hline $\mathrm{T} 2$ & 2400 & 67.58 & $36.50^{\mathrm{ab}}$ & 31.08 & 1.74 & 2.41 & 2.07 & 0.48 & 72.53 \\
\hline T3 & 2300 & 65.80 & $35.02^{b}$ & 30.75 & 2.24 & 2.02 & 2.39 & 0.51 & 70.72 \\
\hline $\mathrm{T} 4$ & 2473 & 67.56 & $37.83^{\mathrm{ab}}$ & 29.72 & 1.99 & 2.44 & 2.18 & 0.54 & 72.71 \\
\hline T5 & 2541 & 68.52 & $37.55^{\mathrm{ab}}$ & 30.95 & 1.88 & 2.25 & 2.25 & 0.47 & 73.49 \\
\hline T6 & 2682 & 66.12 & $36.06^{\mathrm{ab}}$ & 30.06 & 1.55 & 2.48 & 2.46 & 0.50 & 71.57 \\
\hline $\mathrm{T} 7$ & 2404 & 68.40 & $38.57^{\mathrm{a}}$ & 29.79 & 1.90 & 2.59 & 1.87 & 0.52 & 73.38 \\
\hline SME & \pm 100.53 & \pm 0.92 & \pm 0.88 & \pm 0.79 & \pm 0.31 & \pm 0.19 & \pm 0.18 & \pm 0.5 & \pm 0.89 \\
\hline
\end{tabular}

Table (6). Effect of organic acid mixtures on some blood constituents and lymphoid organs of broiler at 42 days.

\begin{tabular}{|c|c|c|c|c|c|c|c|c|}
\hline \multirow[t]{2}{*}{ Items } & \multicolumn{7}{|c|}{ Treatments } & \multirow[t]{2}{*}{ MSE } \\
\hline & $\mathrm{T} 1$ & $\mathrm{~T} 2$ & T3 & $\mathrm{T} 4$ & T5 & T6 & $\mathrm{T} 7$ & \\
\hline \multicolumn{9}{|c|}{ Blood constituents } \\
\hline Calcium & $7.70^{\mathrm{d}}$ & $10.79^{\mathrm{a}}$ & $9.55^{b c}$ & $10.37^{a b}$ & $9.54 \mathrm{bc}$ & $8.70^{\mathrm{cd}}$ & $9.37 \mathrm{bc}$ & \pm 0.37 \\
\hline Phosphorus & $1.11^{\mathrm{d}}$ & $3.38^{\mathrm{a}}$ & $3.23^{b}$ & $1.95^{c}$ & $1.83^{c}$ & $1.95^{\mathrm{cd}}$ & $2.44^{\mathrm{ab}}$ & \pm 0.08 \\
\hline ALT & $87.0^{\mathrm{a}}$ & $75.67^{b}$ & $79.67^{a b}$ & $76.67^{a b}$ & $82.67^{\mathrm{ab}}$ & $83.67^{\mathrm{ab}}$ & $81.00^{\mathrm{a}}$ & \pm 3.30 \\
\hline AST & $36.67^{c}$ & $49.67^{b}$ & $46.33^{\mathrm{b}}$ & $47.00^{\mathrm{b}}$ & $43.00^{\mathrm{bc}}$ & $60.00^{\mathrm{a}}$ & $46.33^{b}$ & \pm 2.31 \\
\hline Cholesterol & $88.63^{\mathrm{a}}$ & $92.33^{\mathrm{a}}$ & $86.36^{\mathrm{a}}$ & $89.52^{\mathrm{a}}$ & $77.06^{\mathrm{ab}}$ & $82.12^{a b}$ & $69.71^{b}$ & \pm 5.08 \\
\hline T. protein & $3.36^{\mathrm{e}}$ & $4.24^{\mathrm{d}}$ & $7.36^{\mathrm{a}}$ & $5.53^{\mathrm{b}}$ & $5.25 \mathrm{bc}$ & $4.42^{\mathrm{cd}}$ & $5.24^{b c}$ & \pm 0.27 \\
\hline Albumin(A) & $0.56^{\mathrm{b}}$ & $0.53^{\mathrm{b}}$ & $1.62^{\mathrm{a}}$ & $0.80^{\mathrm{b}}$ & $0.84^{b}$ & $0.77^{\mathrm{b}}$ & $0.82^{\mathrm{b}}$ & \pm 0.11 \\
\hline Globulin(G) & $2.80^{\mathrm{e}}$ & $3.71^{\mathrm{cd}}$ & $5.74^{\mathrm{a}}$ & $4.72^{b}$ & $4.41 \mathrm{bc}$ & $3.65^{\mathrm{d}}$ & $4.42^{b c}$ & \pm 0.22 \\
\hline $\mathrm{A} / \mathrm{G}$ ratio & $0.20^{\mathrm{b}}$ & $0.14^{\mathrm{b}}$ & $0.29^{\mathrm{a}}$ & $0.17^{\mathrm{b}}$ & $0.19^{\mathrm{b}}$ & $0.20^{\mathrm{b}}$ & $0.19^{b}$ & \pm 0.026 \\
\hline \multicolumn{9}{|c|}{ Lymphoid organs \% } \\
\hline Spleen & $0.14 \mathrm{c}$ & $0.21 \mathrm{a}$ & $0.16 \mathrm{~b}$ & $0.14 \mathrm{c}$ & $0.20 \mathrm{a}$ & $0.13 \mathrm{c}$ & $0.13 \mathrm{c}$ & \pm 0.005 \\
\hline Bursa & $0.16 \mathrm{c}$ & $0.39 \mathrm{a}$ & $0.40 \mathrm{a}$ & $0.37 \mathrm{a}$ & $0.26 \mathrm{~b}$ & $0.28 \mathrm{~b}$ & $0.38 \mathrm{a}$ & \pm 0.014 \\
\hline Thymus & $0.40 \mathrm{~cd}$ & $0.56 \mathrm{a}$ & $0.53 \mathrm{ab}$ & $0.47 \mathrm{bc}$ & $0.47 \mathrm{bc}$ & $0.36 \mathrm{~d}$ & $0.48 \mathrm{~b}$ & \pm 0.023 \\
\hline
\end{tabular}

$a, b \ldots e$ Means in the same row with different superscripts are significantly different $(P<0.01)$.

${ }^{*} \mathrm{Ca}, P$ and cholesterol ( $\left.\mathrm{mg} / \mathrm{dl}\right)$, total protein, albumin and globulin $(\mathrm{g} / \mathrm{dl})$.

$T 1$ (control), T2 (0.5\%FA+0.25\%AC), T3 (0.5\%FA+2\%CA), T4 (0.5\%FA+0.2\%BA, T5 $(0.25 \% A C+2 \% C A), T 6(0.25 \%$ $A C+0.2 \% B A)$ and $T 7(2 \% C A+0.2 \% B A)$. 
Table (7). Effect of organic acid mixtures on measurement of $\mathrm{pH}$ in feed and different parts of the gastrointestinal tract.

\begin{tabular}{|c|c|c|c|c|c|c|c|c|}
\hline Items & & & & Trea & & & & \\
\hline & $\mathrm{T} 1$ & $\mathrm{~T} 2$ & T3 & $\mathrm{T} 4$ & T5 & T6 & $\mathrm{T} 7$ & MSE \\
\hline Starter diet & $5.28^{\mathrm{a}}$ & $4.95^{\mathrm{b}}$ & $4.25^{\mathrm{d}}$ & $4.94^{b}$ & $3.69^{f}$ & $4.64^{c}$ & $4.94^{\mathrm{e}}$ & \pm 0.01 \\
\hline Grower diet & $4.62^{\mathrm{a}}$ & $4.23^{\mathrm{b}}$ & $3.50^{\mathrm{e}}$ & $4.19^{\mathrm{c}}$ & $3.67^{\mathrm{d}}$ & $4.20^{\mathrm{c}}$ & $3.46^{\mathrm{f}}$ & \pm 0.01 \\
\hline Finisher diet & $5.05^{\mathrm{a}}$ & $4.16^{\mathrm{c}}$ & $3.49^{\mathrm{f}}$ & $4.10^{\mathrm{d}}$ & $3.49^{\mathrm{f}}$ & $4.23^{\mathrm{a}}$ & $3.58^{\mathrm{e}}$ & \pm 0.01 \\
\hline Crop & $4.77^{\mathrm{a}}$ & $4.31^{\mathrm{b}}$ & $4.44^{\mathrm{b}}$ & $4.51^{\mathrm{b}}$ & $4.31^{\mathrm{b}}$ & $4.41^{\mathrm{b}}$ & $4.47^{\mathrm{b}}$ & \pm 0.07 \\
\hline Gizzard & $4.48^{\mathrm{a}}$ & $3.62^{\mathrm{bc}}$ & $3.75^{\mathrm{c}}$ & $3.64^{\mathrm{bc}}$ & $3.59^{b c}$ & $3.80^{\mathrm{bc}}$ & $3.91^{\mathrm{b}}$ & \pm 0.11 \\
\hline Duodenum & $5.75^{\mathrm{c}}$ & $5.93^{b c}$ & $5.86^{\mathrm{bc}}$ & $5.82^{b c}$ & $6.33^{\mathrm{a}}$ & $6.20^{\mathrm{a}}$ & $6.10^{a b}$ & \pm 0.12 \\
\hline Jejunum & $5.86^{\mathrm{c}}$ & $6.12^{a b c}$ & $6.12^{a b c}$ & $5.99^{\mathrm{bc}}$ & $6.33^{a b}$ & $6.55^{\mathrm{a}}$ & $6.19^{a b c}$ & \pm 0.07 \\
\hline Ileum & $6.54^{\mathrm{b}}$ & $6.71^{\mathrm{a}}$ & $6.83^{\mathrm{a}}$ & $6.25^{\mathrm{b}}$ & $6.51^{\mathrm{ab}}$ & $6.85^{\mathrm{a}}$ & $6.78^{\mathrm{a}}$ & \pm 0.10 \\
\hline Ceca & $6.07^{\mathrm{b}}$ & $6.43^{\mathrm{ab}}$ & $6.29^{a b}$ & $6.42^{\mathrm{ab}}$ & $6.50^{\mathrm{ab}}$ & $6.70^{\mathrm{a}}$ & $6.02^{\mathrm{b}}$ & \pm 0.18 \\
\hline Rectum & $6.08^{\mathrm{b}}$ & $6.22^{\mathrm{b}}$ & $6.22^{\mathrm{b}}$ & $6.09^{\mathrm{b}}$ & $6.41^{\mathrm{ab}}$ & $6.11^{\mathrm{b}}$ & $6.78^{\mathrm{a}}$ & \pm 0.16 \\
\hline
\end{tabular}

Table (8). Effect of organic acid mixture on ceca microbial content of broiler.

\begin{tabular}{|c|c|c|c|c|}
\hline Items & Lactobacillus & Coliforms & Anaerobes & E. Coli \\
\hline T1(control) & $8.41^{\mathrm{e}}$ & $2.50^{\mathrm{d}}$ & $5.66^{\mathrm{a}}$ & $6.33^{\mathrm{a}}$ \\
\hline $\mathrm{T} 2$ & $8.59^{\mathrm{d}}$ & $3.27^{\mathrm{a}}$ & $4.22^{\mathrm{e}}$ & $5.73^{\mathrm{e}}$ \\
\hline $\mathrm{T} 3$ & $8.34^{\mathrm{f}}$ & $2.40^{f}$ & $4.93^{\mathrm{c}}$ & $5.73^{\mathrm{e}}$ \\
\hline $\mathrm{T} 4$ & $8.33^{\mathrm{f}}$ & $2.43^{\mathrm{e}}$ & $5.49^{\mathrm{b}}$ & $5.87^{\mathrm{d}}$ \\
\hline $\mathrm{T} 5$ & $8.74^{\mathrm{a}}$ & $2.90^{\mathrm{b}}$ & $3.96^{\mathrm{g}}$ & $6.20^{b}$ \\
\hline T6 & $8.72^{b}$ & $2.73^{c}$ & $4.05^{f}$ & $6.21^{\mathrm{b}}$ \\
\hline $\mathrm{T} 7$ & $8.64^{\mathrm{c}}$ & $2.50^{\mathrm{d}}$ & $4.34^{\mathrm{d}}$ & $6.13^{c}$ \\
\hline MSE & \pm 0.005 & \pm 0.006 & \pm 0.005 & \pm 0.006 \\
\hline
\end{tabular}




\section{REFERENCES}

Abdel-Fattah, S.A.; M.H. El-Sanhouty; N.M. El-Madnay and F. Abdel-Azeem (2008). Thyroid activity, some blood constituents, organs morphology and performance of broiler chicks supplemental organic acids. Int. J. Poult. Sci., 7 (3): 215-222.

Akyurek, H.; M.L. Ozduven; A.A. Okur and H.E. Samli (2011). The effects of supplementing an organic acid blend and / or microbial phytase to a corn-soybean based diet fed to broiler chickens. Afr. J. Agric. Res., 6(3):642-649.

AL-Natour, M.Q. and K.M. Alshawabkeh (2005). Using varying levels of formic acid to limit growth of Salmonella gallinarum in contaminated broiler feed. Asian-Aust. J. Anim. Sci., 18: 390-395.

Alp, M.; N. Kocabagli; R. Kahraman; and K. Bostan (1999). Effects of dietary supplementation with organic acids and zinc bacitracin on ileal microflora, $\mathrm{pH}$ and performance in broilers. Turk. J. Vet. Anim. Sci., 23:451-455.

AL-Tarazi, Y.H. and K. Alshawabkeh (2003). Effect of dietary formic and propionic acids on Salmonella Pullorum Shedding and mortality in layer after experimental infection. J. Vet. Med., 50(3):112-117.

Asma, K. and S.S. Nagra (2010). Performance of broiler chicks as influenced by feeding diets supplemented with organic acids. Indian J. Poult. Sci., 45(1):30-34.

A.O.A.C. (1990). Official Methods of Analysis Association of Analytical Chemists.

Ao, T.; A.H. Cantor; A.J. Pescatore; M.J. Ford; J.L. Pierce and K.A. Dawson (2009). Effect of enzyme supplementation and acidification of diets on nutrient digestibility and growth performance of broiler chicks. Poult. Sci., 88:111-117.

Attia, Y.A.; H.F. Ellakany; A.E. Abd El-Hamid; F. Bovera and S.A. Ghazaly (2012). Control of Salmonella enteritidis infection in male layer chickens by acetic acid and/or prebiotics, probiotics and antibiotics. Archiv Für Geflügelkunde, 76 (4): 239-245.Banday, T.; S. Adil; G.A. Bhat; M.S. Mir and M. Rehman (2010). Effect of dietary supplementation of organic acids on performance, intestinal histomorphology, and serum biochemistry of broiler chicken. Vet. Med. Int., 2010:479-485.

Denli, M.; F. Okan and K .Celik (2003). Effect of dietary probiotic, organic acid and antibiotic supplementation to diets on broiler performance and carcass yield. Pakistan J. Nutr., 2:89-91.

Dibner, J. (2004). Organic acids: Can they replace antibiotic growth promoters? Feed Int., 25 (12) 14-16.

Duncan, D.B. (1955). Multiple Range and Multiple F-Tests. Biomettics, 11:1-42.

Ecklund, T. (1983).The antimicrobial effect of dissociated and undissociated sorbic acid at different pH levels. J. Appl. Bacteriol., 54:383-389.

Feed Composition Tables for Animal and Poultry Feedstuffs Used in Egypt, 2001. Technical Bulletin No.1, Central Lab for Feed and Food, Ministry of Agric., Egypt.

Gheisari, A.A.; R.K. Heidari; M. Kermanshahi; Togiani and S. Araeian (2007). Effect of dietary supplementation of protected organic acids (formic) on ileal microflora and protein digestibility in broiler chickens. In Proc. of the $16^{\text {th }}$ Eur. Symp. On Poultry Nutrition. Strasbourg, France. Pp.519-522.

Griminger, P. (1986). Lipid Metabolism. In”Avian Physiology”. P.D. Sturkie. Springer-Verlag, Inc., New York, USA. pp. 345-358.

Gunal, M.; G. Yayli; O. Kaya; N. Karahan and O. Sulak (2006). The effects of antibiotic growth promoter, probiotic or organic acid supplementation on performance, intestinal microflora and tissue of broilers. Int. J. Poult. Sci., 5 (2)149-155.

Hassan, H.M.A.; M.A. Mohamed; Amany W. Youssef and Eman R. Hassan (2010). Effect of using organic acids to substitute antibiotic growth promoters on performance and intestinal microflora of broilers. AsianAust. J. Anim. Sci., 10:1348-1353.

Isabel, B. and Y. Santos (2009).Effects of dietary organic acids and essential oils on growth performance and carcass characteristics of broiler chickens. J. Appl. Poult. Res., 18:472-476.

Islam, K.M.S.; A. Schuhmacher; H. Aupperle and J.M. Gropp (2008). Fumaric Acid in Broiler Nutrition: A Dose Titration study and safety aspects. Inter. J. of Poult. Sci., 7(9):903-907.

Jakobsen, P.E.; K. Grertov and S.H. Nilsen (1960). Fordojeligheds Forog med Fjerkrae "Digestibility trials with poultry" 322 Bereting fra forosgs laboratoriet. Copenhagen, 322(56): 1-43.

Katanbaf, M.N.; E.A. Dunnington and P.B. Siegel (1989). Restricted feeding in early and late-feathering chickens. Growth and physiological responses. Poult. Sci., 68:344-351.

Kirchgessner, M. and F.X. Roth (1988). Ergotrope Effekte durch organische Suren in der Ferkelaufzucht und Schweinemast. bersichten zur Tierernhrung, 16:93-108. Cited from Islam, K.M.S., 2008 a. 


\section{Ghazalah et al.}

Kout Elkloub, M.EL. Moustaf; A.A. Ghazalah; I.A.M. Atta and Riry, F.H. Shata (2014). Effect of dietary supplementation of propionic and butyric acids on performance, nutrients digestibility and health of broiler chicks. 7th International Poultry Conference, 3 - 6 November 2014, Ain Sukhna, Red Sea - Egypt.

Mellor, S. (2000). Nutraceuticals-alternatives to antibiotics. World Poult., 16(2): 30-34.

Mikulski, D.; Z. Zduńczyk; J. Jankowski, and J. Juśkiewicz (2008). Effects of organic acids or natural plant extracts added to diets for turkeys on growth performance, gastrointestinal tract metabolism and carcass characteristics. J. Anim. Feed Sci. Technol., 17: 233-246.

Naidu, A.S. (2000). Natural Food Antimicrobial Systems. CRC Press. USA, pp. 431-462.

Panda, A.K.; S.V.R. Rao; M.V.L.N. Raju and G.S. Sunder (2009). Effect of butyric acid on performance, gastrointestinal tract health and carcass characteristics in broiler chickens. Asian -Aust. J. Anim. Sci., 22(7): 1026-1031.

Patten, L.D. and P.W. Waldroup (1988). Use of organic acids in broiler diets. Poult. Sci., 67: 1178-1182.

Paul, S.K.; G. Samanta; G. Halder and P. Biswas (2007). Effect of a combination of organic acid salts as antibiotic replace on the performance and gut health of broiler chickens .Livest. Res. for Rural Dev., 19 (11):171-175.

Quinn, P.J.; M.E. Carter; B.K. Markey and G.R. Carter (1992). Clinical Veterinary Microbiology. Mosby- Year book Europe limited lynton house, 7- 12 Tavistock square london .pp .61-65. Cited from Paul, S.K., 2007.

Ricke, S.C. (2003). Perspectives on the use of organic acids and short chain fatty acids as antimicrobials. Poult. Sci., 82(4):632-639.

Samanta, S.; H. Sudipto and T.K. Ghosh (2010).Comparative efficacy of an organic acid blend and bacitracin methylene disalicylate as growth promoters in broiler chickens: effects on performance, gut histology, and small intestinal milieu. Vet. Med. Int., 2010:645150.

SAS (1990). SAS/ STAT User's Guide, version 6, $4^{\text {th }}$ Edition. SAS Institute Inc, Cary, NC, USA.

Senkoylu, N.; H.E. Samli; H. Akyürek and A. Agma (2005). Impacts of organic acids and nutrient density of basal diets on broiler growth and gut histomorphology. Proc. $15^{\text {th }}$ European Symp. Poultry Nutrition. 25-29 September 2005, Balatonfured, Hungary. pp. 398-400.

Senkoylu, N.; H.E. Samli; M. Kanter and A. Agma (2007). Influence of a combination of formic and propionic acids added to wheat- and barley-based diets on the performance and gut histomorphology of broiler chickens. Acta. Veterinaria Hungarica, 55(4):479-490.

Smulikowska, S.; J. Czerwiński and A. Mieczkowska (2010). Effect of an organic acid blend and phytase added to a rapeseed cake-containing diet on performance, intestinal morphology, caecal microflora activity and thyroid status of broiler chickens. J. Anim. Physiol. Anim. Nutr., 94(1):15-23.

Sturkie, P.D. (1986). “Avian Physiology”. Springer-Verlag, Inc., New Work, USA, 685 p.

Vale, M.M.; J.M.F. Menten; S.C.D. Moraisand and M.M.A. Brainer (2004). Mixture of formic and propionic acid as additives in broiler feeds. Scientia Agricola Piracicaba, 61:371-375.

Vieira, S.L.; O.A. Oyarzabal; D.M. Freitas; J. Berres; J.E.M. Peña; C.A. Torres and J.L.B. Coneglian (2008). Performance of broilers fed diets supplemented with sanguinarine-like alkaloids and organic acids. J. Appl. Poult. Res., 17(1):128-133.

Viola, E.S.; S.L. Vieira; C.A. Torres; D.M. Freitas and J. Berres (2008). Performance of broilers supplemented with blends of lactic, formic, acetic, and phosphoric acids in the feed or water. Rev. Bras. de Zootec., 37(2): 296-302.

Wolfenden, A.D.; J.L. Vicente; J.P. Higgins; R.L. Andreatti Filho; S.E. Higgins; B.M. Hargis and G. Tellez (2007). Effect of organic acids and probiotics on Salmonella enteritidis infection in broiler chickens. Int. J. Poult. Sci., 6: 403-405. 


\title{
تأثير اضافة مخاليط بعض الأحماض العضوية على الأداء الاتتاجى لكتاكيت التسمين.
}

\author{
عبدالله على غزالة 1, قوت القلوب مصطفى السيد مصطفى²,عبد الرحمن عطا1 و ريرى فوزى شطا2 \\ I قسم الانتاج الحيوانس ـكلية الزراعة. جامعة القاهرة- الجيزة - مصر.

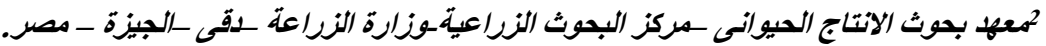

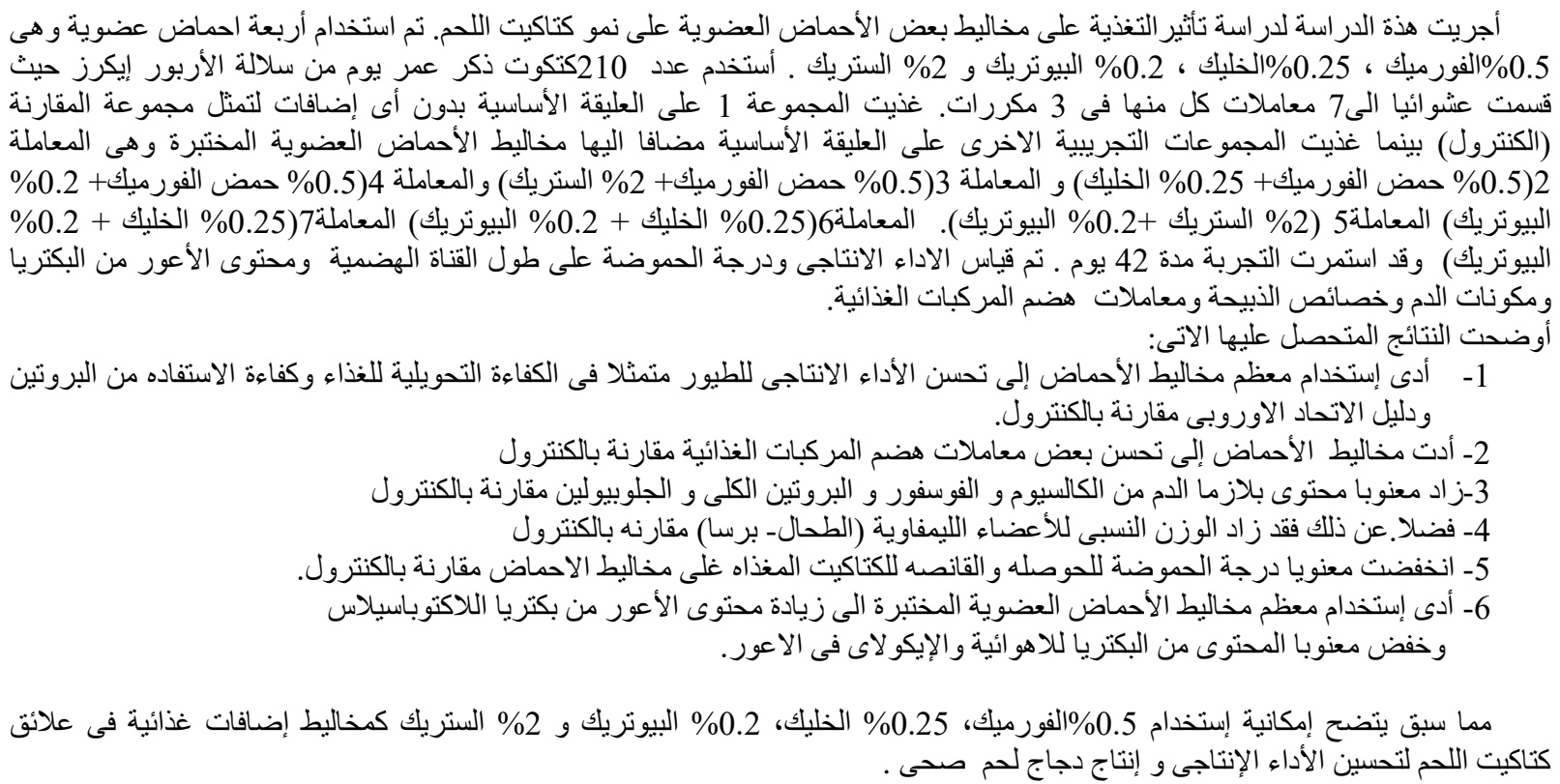

